\title{
Tell me what you study and where you live! Exploring the role that these aspects play when choosing a university
}

\author{
Marta Retamosa ${ }^{1}$, Ángel Millán ${ }^{1}$, Juan A. García ${ }^{2}$ \\ ${ }^{1}$ Department of Marketing, Universidad de Castilla-La Mancha, Ciudad Real, Spain, \\ ${ }^{2}$ Department of Marketing, Universidad de Castilla-La Mancha, Talavera de la Reina, Spain.
}

\begin{abstract}
Previous literature on students' decisions and choices regarding universities contains a large number of factors that influence these process. This research focuses on two of these factors and its aim is twofold. First, it is analyses how prospective students' study areas impact on the relative importance of different university selection criteria. Second, it examines whether the environment of residence (i.e., the size of the municipality) leads to differences in these criteria. The results obtained from a sample of 605 prospective university students who live in the Spanish region of Castilla-La Mancha allowed us to conclude that there were significant differences in most of the selection criteria according to the field of study and the size of the municipality (i.e., five and six out of nine criteria, respectively). Some practical implications for the design of segmentation strategies and communication campaigns in the context of higher education institutions are presented in this work.
\end{abstract}

Keywords: University selection criteria; prospective students; field of study; size of the municipality. 


\section{Introduction}

The literature on the choices and decisions that students make regarding which Higher Education (HE) institutions they should apply to is influenced by a considerable number of factors (Baker, 2019).Little, however, is known about how the students' places of residence (rural or urban areas) influence this decision. The work of Rosvall (2020) stresses that the transition to HE and careers could be more difficult for students in rural areas than for their urban peers. This author also states that students in rural areas are dealing with an ambivalence as regards staying in and leaving rural areas, and the poverty of access that occurs in some cases. Recent studies have indicated the growing gap between rural and urban areas in terms of economic growth, access to social services and employment opportunities (Bernard, 2019; Rignall \& Atia 2017).

Universities compete by employing a variety of marketing techniques, and students subsequently receive their prospectuses and make decisions on the basis of a variety of factors. In this study, we wished to examine whether the selection criteria used depends on the knowledge discipline (degree/career) that the prospective student is planning to study. We additionally considered whether students living in rural or urban areas are influenced as regards the selection criteria employed when choosing their university studies.

\section{Theoretical background}

\subsection{University selection and academic disciplines}

An integrated knowledge of learning and teaching processes across different disciplines requires an in depth understanding of the context and the culture in which the learning process occurs and the attitudes of both academics and students toward teaching, educational goals, values, philosophies and orientations (Neumann, 2001).

Discipline-related differences have been evaluated by focusing on various issues, such as academics' relationship with knowledge, the relationship between students and educators, and the type of expertise that students are supposed to attain (Kemp \& Jones, 2007).

Several previous studies have extensively used the Biglan (1973) classification of academic disciplines (Coughlan \& Perryman, 2011). Biglan proposed a 2x2x2 typology for disciplines by considering three classification criteria (Kember\& Leung, 2011): (1) the degree of consensus paradigm development (hard versus soft); (2) the presence of practical application (pure versus applied), and (3) the presence of a living organism (life versus non-life).

Academic disciplines vary as to their views of the application of practical problems, cognitive processes, concern with life systems, faculty time commitments and scholary output (Becher, 
1987), assessment patterns (Jessop \&Maleckar, 2016) and students' ratings of teaching quality (Kember\& Leung, 2011).

Students' preferences for higher education disciplines can be explained in accordance with their vocation, its innovative nature, the relative strength of its theoretical and practical components, study program efficiency (survival rates), the quality of academic life, the level of the entrance grades required and employment perspectives. Students selecting a university course for the first time generally tend to place great importance on vocation and employment perspectives, while other factors such as the innovative nature of the discipline and the relative strength of its theoretical or practical components are less relevant when planning their academic career (Tavares et al., 2008). However, prospective university students really know very little about the specific characteristics of courses and universities, and there are numerous differences between segments, including particular disciplines (Khanna et al., 2014).

The following hypothesis is, therefore, proposed:

H1. The university selection criteria used by prospective students depend on their field of study.

\subsection{University selection and environment of residence}

University location and distance from home also influence how students plan where and what to study. Many students will generally not travel more than $50 \mathrm{~km}$ in order to study, and this could even be a psychological barrier for many. Students from a better social and economic background may be more likely to travel and place less importance on economic factors and the cost related to higher education. Those who choose not to leave their current home often choose courses from those that are available rather than what they really want to or can do, because those courses are not available locally (Tertiary Education Commission, 2018).

In many countries, students living in rural areas have limited access to career counseling, preparatory college courses, career academies, and school-to-work programs while at high school (Provasnik et al., 2007). This limited access impedes students from gaining the confidence and determination required to see higher education as an option. The study by Griffin et al. (2011) found that when college preparatory resources were limited in rural communities, high school students often looked to their parents/guardians and high school counselors for information.

This challenge is more complex when parents/guardians are less likely to have attended college, and high school counselors are limited as regards the resources they can provide in schools in rural districts. The work of Courrege (2011) stated that guidance counselors play multiple information roles within high schools, from facilitating standardized testing to developing student course schedules. These multiple roles that school counselors perform 
limit the time that they can devote to helping students attain a detailed knowledge of the different university programs and colleges, along with what is required in order to enrol (Courrege, 2011). The following hypothesis is, therefore, proposed:

H2. The university selection criteria used by prospective students depend on the size of the municipality in which they live.

\section{Method and results}

\subsection{University selection and academic disciplines}

This study analyses a sample of 605 questionnaires obtained from students at 15 high schools in the Spanish region of Castilla-La Mancha. A personal survey method was used. There were more female than male respondants $(55.7 \%)$. With regard to the field of study at high school, 31.1\% were studying Social Sciences, 28.9\% Health Sciences, 27.3\% Technological Sciences and $12.7 \%$ Humanities. With regard to the size of the municipality, $39.5 \%$ resided in a village/town with more than 50,000 inhabitants, $25.6 \%$ in one with 10,001 to 20,000 inhabitants, $19.5 \%$ in one between 20,001 and 50,000 inhabitants and $15.4 \%$ in one with less than 10,001 .

The questionnaire included socio-demographic questions (gender, the field of study at high school and the size of the municipality in which the students lived). It also contained nine criteria affecting the choices made by prospective students, which were rated on a 10-point Likert-type scale and based on the work of Joseph et al. (2005). The study additionally included two focus groups comprising university administrators in charge of student recruitment.

\subsection{Results}

The differences in the students' selection criteria according to the field of study at high school and the size of the municipality were studied using the one-way ANOVA procedure when the homogeneous variance assumption was correct, or the Welch Test when the variances were heterogeneous. The Tukey HSD test for equal variances and the Games-Howell test for unequal variances were used as post hoc comparison tests. These statistical analyses were performed using IBM SPSS Statistics 24.0.

As can be seen in Table 1, social science students placed more importance on the city's social and night life, independence from parents and the city's quality of life than did technology students. There were also differences between the former students and those from humanities in the case of the variable "becoming independent from parents". Furthermore, health science students placed more importance on study abroad programs and admission cut-off marks than did social science students. In the case of this last variable, there were statistically significant mean differences between health science students and those from other fields. 
Table 1. Differences in students' selection criteria according to the field of study at high school.

\begin{tabular}{|c|c|c|c|c|c|c|c|c|c|c|}
\hline \multirow[b]{2}{*}{ Selection criteria } & \multicolumn{5}{|c|}{ Mean (M) } & \multicolumn{2}{|c|}{ Levene test } & \multicolumn{2}{|c|}{$\begin{array}{l}\text { ANOVA/ } \\
\text { Welch Test }\end{array}$} & $\begin{array}{l}\text { Post hoc test } \\
\text { Tukey HDS / } \\
\text { Games- } \\
\text { Howell Test) }\end{array}$ \\
\hline & 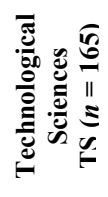 & 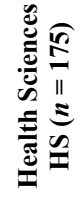 & 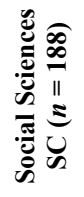 & 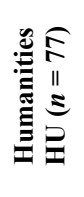 & 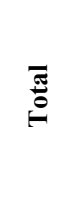 & $F$ & $p$ & $F$ & $p$ & $\mathrm{p}<0.05$ \\
\hline $\begin{array}{l}\text { High school teachers' } \\
\text { advice }\end{array}$ & 3.12 & 3.19 & 3.32 & 3.44 & 3.25 & 1.396 & 0.243 & 0.482 & 0.695 & \\
\hline $\begin{array}{l}\text { Economic aspects } \\
\text { (family income) }\end{array}$ & 4.84 & 4.93 & 5.35 & 5.45 & 5.10 & 0.856 & 0.464 & 1.705 & 0.165 & \\
\hline $\begin{array}{l}\text { Cut-off marks for } \\
\text { admission }\end{array}$ & 7.18 & 8.06 & 6.73 & 6.53 & 7.21 & 4.466 & 0.004 & $11.751^{\mathrm{a}}$ & 0.000 & $\begin{array}{c}\mathrm{HS}>\mathrm{TS}, \\
\mathrm{SC}, \mathrm{HU}\end{array}$ \\
\hline $\begin{array}{l}\text { Social activities/city } \\
\text { night life }\end{array}$ & 5.52 & 6.25 & 6.37 & 6.18 & 6.08 & 1.111 & 0.344 & 3.254 & 0.021 & $\mathrm{SC}>\mathrm{TS}$ \\
\hline $\begin{array}{l}\text { Becoming } \\
\text { independent from } \\
\text { parents }\end{array}$ & 6.65 & 7.33 & 7.65 & 6.27 & 7.11 & 4.048 & 0.007 & $5.769^{\mathrm{a}}$ & 0.001 & $\begin{array}{c}\mathrm{SC}>\mathrm{TS}, \\
\mathrm{HU}\end{array}$ \\
\hline City's quality of life & 7.32 & 7.78 & 7.88 & 7.31 & 7.63 & 2.541 & 0.056 & 2.868 & 0.036 & $\mathrm{SC}>\mathrm{TS}$ \\
\hline $\begin{array}{l}\text { Accommodation } \\
\text { costs (rentals) }\end{array}$ & 7.17 & 7.46 & 7.53 & 7.27 & 7.38 & 2.759 & 0.042 & $0.683^{\mathrm{a}}$ & 0.563 & \\
\hline $\begin{array}{l}\text { Study abroad } \\
\text { programmes }\end{array}$ & 6.25 & 6.95 & 6.07 & 6.60 & 6.44 & 3.808 & 0.010 & $3.294^{\mathrm{a}}$ & 0.021 & $\mathrm{HS}>\mathrm{SC}$ \\
\hline $\begin{array}{l}\text { Internships/practicum } \\
\text { programmes }\end{array}$ & 7.49 & 7.07 & 7.27 & 6.77 & 7.21 & 2.125 & 0.096 & 1.746 & 0.156 & \\
\hline
\end{tabular}

Note: ${ }^{a}$ Asymptotically F distributed.

Table 2 shows that students living in larger municipalities (with more than 50,000 inhabitants) placed less importance on the following criteria: "becoming independent from parents", "city's quality of life" and "accommodation costs (rentals)", than did the rest of the students. The criteria "cut-off marks for admission" and "social activities/city night life" were more important for students from municipalities of between 20,001-50,000 inhabitants than for those living in municipalities with more than 50,000 inhabitants. Lastly, economic aspects were less important for students living in a municipally of less than 10,001 inhabitants. 
Table 2. Differences in students' selection criteria according to the size of the municipality.

\begin{tabular}{|c|c|c|c|c|c|c|c|c|c|c|}
\hline \multirow[b]{2}{*}{$\begin{array}{c}\text { Selection } \\
\text { criteria }\end{array}$} & \multicolumn{5}{|c|}{ Mean (M) } & \multicolumn{2}{|c|}{ Levene test } & \multicolumn{2}{|c|}{$\begin{array}{c}\text { ANOVA/ } \\
\text { Welch Test }\end{array}$} & \multirow{2}{*}{$\begin{array}{c}\begin{array}{c}\text { Post hoc test } \\
\text { (Tukey HDS } \\
\text { / Games- } \\
\text { Howell Test) }\end{array} \\
\\
p<0.05\end{array}$} \\
\hline & 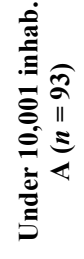 & 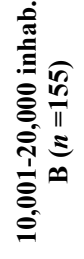 & 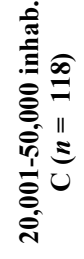 & 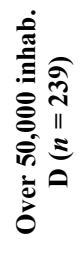 & $\stackrel{5}{0}$ & $F$ & $p$ & $F$ & $p$ & \\
\hline $\begin{array}{l}\text { High school } \\
\text { teachers' advice }\end{array}$ & 2.92 & 3.19 & 3.54 & 3.26 & 3.25 & 2.152 & 0.093 & 1.395 & 0.243 & \\
\hline $\begin{array}{l}\text { Economic } \\
\text { aspects (family } \\
\text { income) }\end{array}$ & 4.31 & 5.65 & 5.00 & 5.10 & 5.10 & 1.665 & 0.173 & 4.807 & 0.003 & $\mathrm{~B}>\mathrm{A}$ \\
\hline $\begin{array}{l}\text { Cut-off marks for } \\
\text { admission }\end{array}$ & 7.35 & 7.06 & 7.73 & 7.00 & 7.21 & 2.722 & 0.044 & $2.695^{\mathrm{a}}$ & 0.046 & $C>D$ \\
\hline $\begin{array}{l}\text { Social } \\
\text { activities/city } \\
\text { night life }\end{array}$ & 6.20 & 6.37 & 6.41 & 5.68 & 6.08 & 1.100 & 0.348 & 2.944 & 0.032 & $C>D$ \\
\hline $\begin{array}{l}\text { Becoming } \\
\text { independent from } \\
\text { parents }\end{array}$ & 7.75 & 7.99 & 7.87 & 5.90 & 7.11 & 30.470 & 0.000 & $20.910^{\mathrm{a}}$ & 0.000 & $\mathrm{~B}, \mathrm{C}, \mathrm{A}>\mathrm{D}$ \\
\hline $\begin{array}{l}\text { City's quality of } \\
\text { life }\end{array}$ & 7.82 & 7.97 & 8.03 & 7.13 & 7.63 & 6.845 & 0.000 & $6.891^{\mathrm{a}}$ & 0.000 & $\mathrm{C}, \mathrm{B}, \mathrm{A}>\mathrm{D}$ \\
\hline $\begin{array}{l}\text { Accommodation } \\
\text { costs (rentals) }\end{array}$ & 7.76 & 7.88 & 7.88 & 6.66 & 7.38 & 10.311 & 0.000 & $10.338^{\mathrm{a}}$ & 0.000 & $\mathrm{~B}, \mathrm{C}, \mathrm{A}>\mathrm{D}$ \\
\hline $\begin{array}{l}\text { Study abroad } \\
\text { programmes }\end{array}$ & 5.89 & 6.54 & 6.59 & 6.51 & 6.44 & 0.154 & 0.927 & 1.325 & 0.265 & \\
\hline $\begin{array}{l}\text { Internships/practi } \\
\text { cum programmes }\end{array}$ & 7.00 & 7.35 & 7.17 & 7.21 & 7.21 & 0.246 & 0.864 & 0.390 & 0.760 & \\
\hline
\end{tabular}

Note: ${ }^{a}$ Asymptotically $F$ distributed.

\section{Conclusions}

The results of this research provided empirical support for the two study hypotheses (H1 and $\mathrm{H} 2$ ). With regard to $\mathrm{H} 1$, it was possible to conclude that the relative importance of five out of the nine university selection criteria considered varied according to the to the field of study at high school. The most noticeable differences specifically appeared among social sciences students and those from other fields. Career-focused degrees - such as business, education and law - are more prevalent at less selective schools than are pure sciences degrees. Some 
previous studies emphasize the relevance of studying the connection between degrees and fields of study at the graduate degree level (Becker \&Toutkoushian, 2013). With regard to $\mathrm{H} 2$, the size of the municipality of residence had a significant impact on almost all the university selection criteria, with the sole exceptions of high school teachers' advice, study abroad programs and intersihips/practicum programs. These results are consistent with previous studies that have highlighted the importance of the environment of residence (rural versus urban) in the choice of university (Rosvall, 2020).

The discovery of differences or similarities between disciplines and students' sociodemographic backgrounds are a foundation on which many questions related to communication strategies could be analysed, in addition to the nature and composition of the organizational structure of multidisciplinary HE institutions. From a practical point of view, the results obtained are useful for the design of HE institutions' communication campaigns. On the one hand, the field of study and the environment of residence are two potentially relevant criteria or segmentation bases for the design of marketing strategies aimed at attracting prospective university students. On the other, the effectiveness of a specific communication tool used to to reach a particular target audience could be improved if the relative importance of the different university selection criteria were taken into account.

\section{References}

Baker, Z. (2019). The vocational/academic divide in widening participation: the higher education decision making of further education students. Journal of Further and Higher Education, 44(6), 766-780. doi:10.1080/0309877X.2019.1599328

Becher, T. (1987). The disciplinary shaping of the profesion. In B.R. Clark (Ed.), The academic profession: National, disciplinary and institutional settings (pp. 271-303). Berkeley, CA: University of California Press.

Becker, W. E., \& Toutkoushian, R. K. (2013). On the meaning of markets in higher education. In M. Paulsen (Ed.), Higher education: Handbook of theory and research (pp. 323-376). Dordrecht, Netherlands: Springer.

Bernard, J. (2019). Where have all the rural poor gone? Explaining the rural-urban poverty gap in european countries. Sociologia Ruralis, 59(3), 369-392. doi:10.1111/soru.12235

Biglan, A. (1973). The characteristics of subject matter in different scientific areas. Journal of Applied Psychology, 57(3), 195-203. doi:10.1037/h0034701

Coughlan, T., \& Perryman, L. A. (2011). Something for everyone? The different approaches of academic disciplines to open educational resources and the impact on widening participation. Journal of Open, Flexible, and Distance Learning, 15(2), 11-27. Retrieved from https://files.eric.ed.gov/fulltext/EJ1079986.pdf

Courrege, D. (2011). Helping rural students leap cultural hurdles to college. Education Week. Retrieved from https://www.edweek.org/teaching-learning/helping-rural-students-leapcultural-hurdles-to-college/2011/10 
Griffin, D., Hutchins, B. C., \& Meece, J. L. (2011). Where do rural high school students go to find information about their futures?. Journal of Counseling \& Development, 89(2), 172-181. doi:10.1002/j.1556-6678.2011.tb00075.x

Jessop, T., \& Maleckar, B. (2016). The influence of disciplinary assessment patterns on student learning: a comparative study. Studies in Higher Education, 41(4), 696-711. doi:10.1080/03075079.2014.943170

Joseph, M., Yakhou, M., \& Stone, G. (2005). An educational institution's quest for service quality: customers' perspective. Quality Assurance in Education, 13(1), 66-82. doi:10.1108/09684880510578669

Khanna, M., Jacob, I., \& Yadav, N. (2014). Identifying and analyzing touchpoints for building a higher education brand. Journal of Marketing for Higher Education, 24(1), 122-143. doi:10.1080/08841241.2014.920460

Kember, D., \& Leung, D. Y. P., (2011). Disciplinary differences in student ratings of teaching quality. Research in Higher Education, 52(3), 278-299. doi:10.1007/s11162-010-9194-Z

Kemp, B., \& Jones, C. (2007). Academic use of digital resources: Disciplinary differences and the issue of progression revisited. Journal of Educational Technology \& Society, 10(1), 52-60. Retrieved from https://www.jstor.org/stable/jeductechsoci.10.1.52

Neumann, R. (2001). Disciplinary differences and university teaching. Studies in Higher Education, 26(2), 135-146. doi:10.1080/03075070120052071

Provasnik, S., KewalRamani, A., Coleman, M. M., Gilbertson, L., Herring, W., \& Xie, Q. (2007). Status of education in rural America. US Department of Education, National Center for Education Statistics, Institute of Education Sciences.

Rignall, K., \& Atia, M. (2017). The global rural: Relational geographies of poverty and uneven development. Geography Compass, 11(7), e12322. doi:10.1111/gec3.12322

Rosvall, P. A. (2020). Counselling to stay or to leave?-Comparing career counselling of young people in rural and urban areas. Compare: A Journal of Comparative and International Education, 50(7), 1014-1032. doi:10.1080/03057925.2020.1760788

Tavares, D., Tavares, O., Justino, E., \& Amaral, A. (2008). Students' preferences and needs in Portuguese higher education. European Journal of Education, 43(1), 107-122. doi:10.1111/j.1465-3435.2007.00331.x

Tertiary Education Commission (2018). 'Transition to tertiary life' event: entering and reentering tertiary education in New Zealand: prediscovery report. 